\title{
The Impact of Epidemic-related Depopulation and the Theory of Labour Value by Ibn Khaldun in the 14 ${ }^{\text {th }}$ Century
}

\section{Hussain M. A. Al-Obaid}

College of Administrative \& Financial Science

Department of Administrative Science

KKU Abha, Kingdom of Saudi Arabia

hussainalobaid@yahoo.com 



\section{The Impact of Epidemic-related Depopulation and the Theory of Labour Value by Ibn Khaldun in the 14th Century}

\section{Abstract}

The terrible epidemic that struck the Middle East, North Africa and Europe in 1347-1350, killed one-third of the population and had a traumatic effect on human civilization. Workers became exceedingly scarce and marked increases in prices for commodities ensued. Black Death had a tremendous personal impact on Ibn Khaldun's early theory of labour value as populations vanished in the middle of the $14^{\text {th }}$ century. His invaluable contribution to economic theories makes him the precursor as centuries later great economists such as Smith, Ricardo and Marx harked back upon his inductive empirical postulates, rather than on mere theoretical assumptions. 


\section{Vignette of Olbn Khaldun (1332-1406)}

Ibn Khaldun (1332-1406) is the $14^{\text {th }}$ century economist, noted for his innovative theories embodying the principle that labour is the source of value. Born on 27 May 1332, he spent most of his childhood in Tunisia, Morocco and Spain. Coming from a prestigious family background in politics and scholars, he received an excellent classical education with Islam as the basis for his values and conviction. He memorised the Qur'an by heart, learnt grammar, jurisprudence, hadith, rhetoric, philosophy and poetry. When he was just about 17, the epidemic infamously know as Black Death reached his city, claiming the lives of many, including his parents and several of his relatives and scholars. This tragic event was the catalyst that finally shaped and moulded Ibn Khaldun's perception of the world. ${ }^{1} \mathrm{He}$ travelled extensively from Tunisia, to Morocco, Spain, Damascus, Algeria, and Egypt. Famed as the forerunner of modern historiography, he wrote profusely on various subjects of philosophy, history, logic and political economy. He was first brought to Western attention in 1697 and thereafter gained considerable recognition. As an ambitious and brilliant young man, he first served as Chancellery to the leader of Tunis at age 20 and was imprisoned for 22 months for joining the revolt against the Sultan. He later became a member of the Council of Ulema (Scholars) in Morocco and then lectured at Al Azhar and other prestigious schools in Egypt where he died in his last duty as the Malikite Qadi (Judge) at age 74. In 2006, Spain commemorated his $600^{\text {th }}$ death anniversary. ${ }^{2}$

${ }^{1}$ Lewis, Sources for the Economic History of the Middle East, in: M. A. Cook, ed. Studies in the Economic History of the Middle East. pp. 78-92.

${ }^{2}$ Ibn Khaldun, Wikipedia, the free encyclopedia. Retrieved on 29 May 2012. 


\section{The Black Death Epidemic of the $14^{\text {th }}$ Century}

One of the most common mysteries in European and the Middle East economic history, and definitely in Economics itself, is the $14^{\text {th }}$ century epidemic - Black Death - of 1347-50. Suffice to say that epidemics were not uncommon during that time. However, what distinguished Black Death from other natural human destruction was its severity. It was a question surviving or dying - a desperate life and death ordeal. Running for their life, thousands of people attempted to flee before the overwhelming attack of Black Death approached them. But the horror was unrelenting - too little, too late. Ibn Khaldun wrote that the epidemic simply 'swallowed up many of the good things' and 'wiped them out.' He concluded: 'The world changed. How could it ever be the same?'3 This sweeping epidemic did not discriminate in its path of death and destruction. As the people fled for their safety, they carried Black Death with them, spreading the horrible epidemic wherever they went. But, there was no escaping this engulfing plague. The reality of this panic was difficult to grasp or scientifically comprehend, as all they could rely on was superstition, pure and simple. It was something of an astounding mystery. ${ }^{4}$ Indeed, the legends and episodes of death and destruction come to fore, as we begin to see how people react in times of great suffering, calamities and tragedies, such as murder, abandonment, and acts of senseless cruelty and destruction. Some deaths resulted as a direct consequence of conscious neglect or dire starvation,

\footnotetext{
${ }^{3}$ Nashat, Ibn Khaldun Pioneer Economist.

${ }^{4}$ Boccaccio, The Decameron vol. I
} 
and not from the disease itself. ${ }^{5}$ Giovanni Boccaccio wrote, 'Many dropped dead in the open streets by day and night.' Bodies were 'here, there and everywhere.' With so much death everywhere, death rituals were forgotten and, moreover, burial rites and traditions were altogether abandoned. Ibn Khaldun described this tumultuous and destructive episode of civilization thus:

Civilization decreased with the decrease of mankind. Cities and buildings were laid waste, roads and way signs were obliterated, settlements and mansions became empty, dynasties and tribes grew weak. The entire inhabited world changed. The East, it seems, was similarly visited, though in accordance with and in proportion to (the East's more affluent) civilization. It was as if the voice of existence in the world had called out for oblivion and restriction, and the world had responded to its call. ${ }^{6}$

To acknowledge, some areas were little affected by the epidemic, but where it struck, it took in its indiscriminate path of destruction tremendous numbers of people and laid waste the very foundation of human civilization. Accurate statistics are not available for this period for all affected areas, but there were places where as much as a third of the population perished. The incidence of the plague varied with social position: poor

5 Kelly, The Great Mortality, An Intimate History of the Black Death, the Most Devastating Epidemic of All Time.

6 Ibn Khaldun, The Muqaddimah: An Introduction to History, p. 215-219 
city workers, crowded together in unsanitary conditions from which they could not hope to escape, suffered the greatest number of casualties. Indeed, Black Death proved astoundingly enduring long after its initial visit in 1347. Although considered exhausted by 1350, the disease remained widespread, recurring in some places until the seventeenth century. ${ }^{7}$ The toll is staggering: the epidemic is estimated to have killed 30 to $60 \%$ of the European and Middle East population, reducing the world's then population from an estimated 450 million to between 350 and 375 million by $1400 .^{8}$ This has resulted in creating a series of religious, social and economic disturbances which had profound effects on that period of European and Middle Eastern history. The recovery was drawn out as many survivors have never lived to see it: it took 150 years for the world's population to recover. The epidemic returned at various times, resulting in a larger number of deaths, until it finally left Europe in the $19^{\text {th }}$ century. ${ }^{9}$

\section{The Impact of the $14^{\text {th }}$ Century Depopulation on Economics}

Black Death led to a sudden rise in real wages, for both agricultural labourers and urban artisans. As a result, this was touted as the Golden Age of the Labourer, lasting until the early $16^{\text {th }}$ century. While there is no doubt that real wages in the mid- to late- $15^{\text {th }}$ century in

${ }^{7}$ Postan, Some Economic Evidence of Declining Population in the Later Middle Ages.

8 Ibid.

${ }^{9}$ Williman, ed. The Black Death: The Impact of the Fourteenth Century Epidemic. 
England, for instance, peaked far higher than that ever achieved in past centuries ${ }^{10}$, craft wages and prices remained far higher in England and many effected areas than before. That was true in the cities of mainland Europe too, as in Florence they had doubled. ${ }^{11}$ Thus the undisputed rise in nominal or money wages following Black Death was literally swamped by the post-epidemic inflation, so that, in effect, real wages fell. Conversely, the rise of real wages in the second quarter of the fourteenth century was principally due to a deflation in which consumer prices fell much more than nominal wages did. ${ }^{12}$ Governments swiftly brought in laws to stop the free movement of farm labour and restore pre-epidemic wage levels, fining employers who paid more. It was partially effective. Food prices rose rapidly as, for instance, in the 1350s, grain cost 30\% more than before. Farm wages fell, but still stayed far above past levels. Unsurprisingly, not just did the attempt to reverse them defy market realities, but the levels fixed, had in some places, surpassed years before the epidemic struck. ${ }^{13}$

10 Postan, op. cit.

${ }^{11}$ Herlihy, The Black Death and the Transformation of the West.

12 Hamilton, Money, Prices, and Wages in Valencia, Aragon, and Navarre, 1351-1500.

${ }^{13}$ Dols, The Second Epidemic Pandemic and its Recurrences in the Middle East: 1347-1894. 


\section{The Rise of Labour Value Theory and Ibn Khaldun's Contributions}

Ibn Khaldun was introduced to the West in the early $19^{\text {th }}$ century when some of his writings were translated into French by Silvestre de Sacy in 1806 In the field of economics, primarily due to the efforts of Nashat $^{14}$, Issawi ${ }^{15}$, Spengler ${ }^{16}$, Boulakia ${ }^{17}$, Essid ${ }^{18}$, and Kuran ${ }^{19}$, Ibn Khaldun is relatively well known. ${ }^{20}$ In economics, Ibn Khaldun's writings cover almost every foundation of modern economic thought, ranging from microeconomics to international trade. It is no surprise at all that one finds almost one third of his AlMugaddimah consists of socio-economic concepts. He developed the concepts in such a way that they are interconnected to one another. Thus, one will not understand a particular concept without knowing the basic ideas about others. ${ }^{21}$ Ibn Khaldun has dealt with economics, sociology, political science and other subjects in order to understand the behaviour of man and his history especially, after the massive shortage of population caused by 1347-1350 epidemic.

Due to scope limitation, this paper will only discuss the element of microeconomics 'labour value theory' in Ibn Khaldun's writing. He first propounded that

\footnotetext{
${ }^{14}$ Nashat, op. cit.

15 Issawi, An Arab Philosophy of History.

${ }^{16}$ Spengler, Economic Thought of Islam: Ibn Khaldun.

17 Boulakia, Ibn Khaldun: A Fourteenth-Century Economist.

${ }^{18}$ Essid 1987 Reference for this source not cited???

${ }^{19}$ Kuran 1987 Reference for this source not cited???

20 Boulakia, op. cit.

${ }^{21}$ Bernardelli, The Origins of Modern Economic Theory.
} 
specialization is the major source of economic surplus, almost three centuries before Adam Smith. Ibn Khaldun is one of the few successful theoreticians who have analyzed the behaviour of human beings and of society as an integrated whole in their totality, as part of greater humanity, in the rise and fall of civilization paralleled to the rise and fall of economic surplus, respectively. For him, the cycle of the civilization has reached its end with the destruction of superstructure. ${ }^{22}$ On the import of specialization, he contends:

Each particular kind of craft needs persons to be in charge of it and skilled in it. The more numerous the various subdivisions of a craft are, the larger the number of the people who (have to) practice that craft. The particular group (practicing that craft) is coloured by it. As the days follow one upon the other, and one professional colouring comes after the other, the crafts-colouring men become experienced in their various crafts and skilled in the knowledge of them. Long periods of time and the repetition of similar (experiences) add to establishing the crafts and to causing them to be firmly rooted. ${ }^{23}$

Ibn Khaldun's description of the productive processes implies a production function with a single variable input: labour. He argued that the labour input of a city determines the total output of that community. To maximize revenue and utility level, man should be free

22 Nashat, op. cit.

${ }^{23}$ Ibn Khaldun, op. cit., p. 236-237 
to do what is led by their talent and ability. Through natural talent and learnt ability, man can freely produce high quality objects, and often more work-unit per hour, in other words, greater productivity. According to Ibn Khaldun, labour is the source of value. Ibn Khaldun considers both workers and entrepreneurs as respected members of the society who try to maximize the return for their activities in the form of wages and profits. For him, the profit is the primary motive of economic endeavour, since the expectation and indeed motivation of profit leads naturally and logically to the expansion of production. Moreover, for him, 'commerce means the attempt to make a profit by increasing capital, through buying goods at a low price and selling them at a high price.' In other words, 'the truth about commerce' is to 'buy cheap and sell dear.' Ibn Khaldun expounded in detail his theory of labour value and presented it for the first time in the history of human civilization, thus:

...everything in the world is purchased with labour. What is purchased with money or other good is purchased by labour, inasmuch as gained by labour from our body. Money or commodities indeed save us. They contain certain quantity value of labour that we exchange for what it should be, when it contains the same quantity. The value of a commodity for those who own it, and those who do not use it for himself, but exchange it with other commodity, therefore, equal to labour quantity that enable him purchasing or, directing it. 
Labour, therefore is a real measure of exchangeable value of all commodities. ${ }^{24}$

On the other hand, Ibn khaldun clearly indicated that the profit human beings make is the value realized from their labour. For him, 'large profits' is attributed to large amounts of (available) labour, which is the cause of profit. However, Ibn Khaldun considered not only the activities of the workers, but of entrepreneurs to be productive as well and further insisted that profit is the value realized from labour:

It should be further known that the capital a person earns and acquires, if resulting from a craft, is the value realized from his labour; it has, thus, become clear that gains and profits in their entirety or for the most part, are value realized from human labour. ${ }^{25}$

Analysing his theory, Baeck has rightly declared that 'the value of each product, according to Ibn Khaldun is equal to the amount of work put into it.'26 In other words, the more input that goes into producing a particular commodity, the higher is the value of that commodity. According to Ibn Khaldun, although commodity value comprises cost from raw material and natural resources, it is through labour that value increases and hence, wealth is generated and grows. Thus, without man's effort, the opposite will occur.

${ }^{24}$ Ibn Khaldun, op. cit., p. 325-326

25 Ibn Khaldun, The Muqaddimah: An Introduction to History.

Volume I, II, III. p. 313.

${ }^{26}$ Baeck, The Mediterranean Tradition in Economic Thought, p. 23 
In analysing and interpreting Ibn Khaldun's theory on work, it is clear that labour is both a necessary and sufficient condition for revenue while natural resources are only a necessary condition. Labour and effort are expended in order to produce, which in turn is used against an exchange through barter, or through the use of money, namely gold and silver. Moreover, Ibn Khaldun underscores the vital role of extra effort in the production process that is later known as marginal productivity, in the welfare of a given society. However, despite its appeal, it is clear that Ibn Khaldun's conception of the utility theory of value, like his insights with respect to labour theory of value, were rudimentary. ${ }^{27}$

His theory on labour provides the reason for the increase of cities, such as one indicated by his historical analysis that becomes a major element of civilization. He submits:

A civilization generates large profit (income) due to large number of labour force that is the cause of profit...Labour is necessary for revenues and capital accumulation. This is obvious in the case of manufacture (craft). Even if revenue generated from something other than manufacture, the value of generated profit (and capital) should cover labour value by which the commodity is obtained. Without labour, all other things will not be acquired. ${ }^{28}$

27 Ibn Khaldun, op. cit.

28 Ibid, p. 334 
The process hence generates revenue and profit that are acquired by man from a manufacture/commodity as value of his labour, after deducting the cost of raw material. Ibn Khaldun divides all revenues into two categories: gross revenue and life revenue. Gross revenue is secured when man works for himself and sells his product to others. In this context the value should contain the cost of raw material and natural resources. Life revenue is achieved when man works for himself. Therefore gross revenue means profit, depending on the context. In this instance, life revenue means gross revenue because raw material cost and natural resources are included in the selling price of a commodity. ${ }^{29}$ Ibn Khaldun also explains the causes of different labour revenue. According to him, by specialization and division of labour, some producers are able to generate surplus products, and through exports to other communities and satisfying the luxury wants of the consumers, these producers are able to amass a great deal of wealth.

The accumulation of this wealth might be caused by differences in skills, market size, location, expertise (craftsmanship) or work, and from how far the authority and governors purchase the final products. When a certain kind of labour becomes more expensive, namely if the demand exceeds available supply, revenue is bound to increase. High returns in manufacture will attract other players. This is a dynamic phenomenon that effectively increases available supply, and drives the profit margin down. This principle explains how original Ibn Khaldun's idea was in

${ }^{29}$ Koutsoyiannis, Modern Microeconomic. 
adjusting long term labour between certain professions and others. However, this point of view was attacked by John Maynard Keynes in his famous statement that in the long run we are all dead. Nevertheless, Ibn Khaldun's analysis has not only proved to be historically correct, but has also constituted the core thinking of classical economists in modern times. Ibn Khaldun succinctly observed, explained, and analyzed the variation of earnings in one place being different from another. This variation or difference in earnings is directly related to each town's own degree of wealth and standard of living, which in themselves are to be achieved through the fruits of labour and the crystallization of productive communities. Ibn Khaldun further asserts on the need of a free economy, a free market and free choice. Quoted from his famous AlMuqaddima:

Among suppressive action and very perilous measure to the people is to compel someone to do forced work unjustly. Because labour is a commodity, like the one we will show later, in income and profit, representing work value of its recipient...Unfortunately most people do not have income source other than his own labour. Therefore, if they are forced to work for what they achieved through training, or compelled to do work in their own field, they will lose the result of their work, and pulled out of the greatest part of, even all, their income. ${ }^{30}$

30 Ibn Khaldun, op. cit., p. 336 
Ibn Khaldun observes precisely how income may differ from one place to another, even for similar professions. Income for judges, craftsmen or even burglars, for instance, is directly related to the welfare level and living standard in every given city, achieved through the result of labour and crystallization of a productive society. More effort produces more and less effort less and even a reversal to an opposite direction may occur.

Adam Smith explained differences in labour earnings by comparing them in England and in Bengal along the same lines of reasoning propounded by lbn Khaldun who did so four centuries earlier, as he compared earnings in specific jobs with those of other jobs. Indeed, Long before David Ricardo published his significant contribution in the field of economics in 1817, The Principles of Political Economy and Taxation, Ibn Khaldun expounded the original explanation for the reasons behind the differences in labour earnings. ${ }^{31}$

\section{Parallelism of the Historical Contributions of Ibn Khaldun}

As Nashat puts it, what is abundantly clear is that Ibn Khaldun had

...discovered a great number of fundamental economic notions a few centuries before their official births. He discovered the virtues and the necessity of a division of labour before Smith and

${ }^{31}$ Oweiss, Ibn Khaldun, Father of Economics. 
the principle of labour value before Ricardo and the role of government in stabilization policy before Keynes. ${ }^{32}$

The subject of value received increasing importance ever since economics became a science. Adam Smith (1723-1790) forcefully presented Labour Theory of Value but 'confused' it with the Cost of Production Theory of Value. ${ }^{33}$ David Ricardo (1772-1823) attempted to address Smith's 'inconsistency' but was himself not free of confusion. ${ }^{34}$ Karl Marx (1811-889) tried to take the Smithian and Ricardian labour theory of value to its logical conclusion by presenting the theory of exploitation ${ }^{35}$ to invite opposition from every corner. Marginalist school emphasized the demand side or a 'theory of value based on utility as an alternative to the classical theory ${ }^{\prime 36}$ against the classical emphasis of supply side economics. Neo-classical economists further tried to put an end to this controversy by combining both demand and supply in determination of the value. ${ }^{37}$ With the exception of Joseph A. Schumpeter, who discovered Ibn Khaldun's invaluable work only a few months before his death, Joseph J. Spengler, and Charles Issawi, major Western economists trace the theory of value to Adam Smith and David Ricardo because they attempted to find a reasonable explanation for the paradox of value.

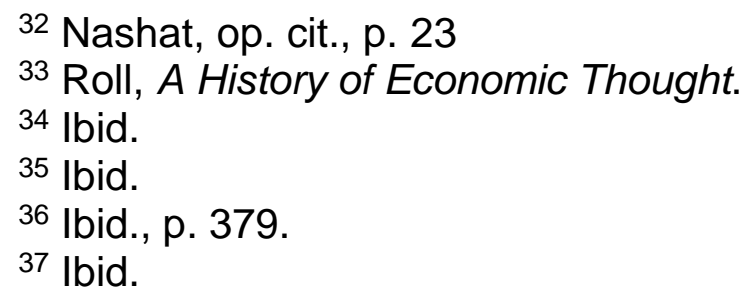


According to Adam Smith and as further developed by David Ricardo, the exchange value of objects is to be equal to the manual labour time used in its production. On the basis of this concept, Karl Marx concluded that the 'wages of labour must equal the production of labour' and thereby introduced his revolutionary term surplus value, signifying the unjustifiable reward given to capitalists, who exploit the efforts of the labour class, or the proletariat. Notwithstanding, it was Ibn Khaldun, a firm advocate of the free market economy, who first introduced the labour theory of value without the extensions of Karl Marx. ${ }^{38}$ For Ibn Khaldun, labour is the source of value. He offered a detailed account of his labour theory of value, presenting it for the first time in history. It is worth noting that Ibn Khaldun never called it a 'theory' per se, but had profoundly presented it as succinctly captured in volume 2 of Rosenthal's translation in his analysis of labour and its efforts.

Ibn Khaldun's contribution was later picked up by David Hume in his Political Discourses, published in 1752: 'Everything in the world is purchased by Labour.' This quotation was even used by Adam Smith as a footnote. ${ }^{39}$ Value theory thus formed the foundation of classical and Marxian political economy. A discussion of theories of value is present in Al-Mugaddimah but it does not occupy such a prominent role in Ibn Khaldun's writings as it does in the classical and Marxian expositions. For Ibn Khaldun, it is clear that 'the profit human beings make is the value realized from their

38 Oweiss, Ibn Khaldun, Father of Economics.

${ }^{39}$ Hume, Political Discourses: Bilingual English-French (17521758). 
labour', but this value, the price of labour, is determined by the law of supply and demand. These points were missed by Karl Marx and his ardent followers. For lbn Khaldun, the coordination, cooperation and direction of factors of production in increasing economic surplus is a productive and costly process which is undertaken by entrepreneurs who try hard to make a significant gain for their economic activities. They invest time, energy and capital in search of goods and services to buy cheap and sell dear, in order 'to make huge profits. As a result, Ibn Khaldun praised the initiatives of entrepreneurs for their productive activities in coordinating and directing the factors of production. Thus, they very rightly deserved profit from their risky undertakings and ventures. Accordingly, Karl Marx, Ricardo and others went astray on this vital point as well. ${ }^{40} \mathrm{lbn}$ Khaldun's treatment of the determinants of value of the commodities in many respects resembles but is not as well-developed as the theories of value espoused by Smith, Ricardo, and Marx. Moreover, his remarks associating utility derived from real estate and its price is a prelude to the utility theory of value. ${ }^{41}$

The parallel between Adam Smith's labour theory of value and Ibn Khaldun's labour theory of value is indeed very striking. Smith commenced his labour theory of value by claiming that: 'Labour was the first price, the original purchase - money that was paid for all things. It was not by gold or by silver, but by labour, that all the wealth of the world was originally

40 Nashat, op. cit.

${ }^{41}$ Essid, op. cit. 
purchased.'42 Whereas Ibn Khaldun developed his value theory by insisting that: 'There is nothing here [originally] except the labour, and [the labour] is not desired by itself as acquired [...but the value realized from it]. ${ }^{43}$ He further expanded on this theme by positing:

Carpentry and weaving, for instance, are associated with wood and yarn [the respective craft needed for their production]. However, in the two crafts [first mentioned] the labour [that goes into them] is more important, and its value is greater. ${ }^{44}$

He further contends that: 'It has thus become clear that gains and profits, in their entirety or for the most part, are value realized from human labour. ${ }^{35}$ And earlier, he defined profit as: '[The part of income] that is obtained by a person through his own effort and strength is called "profit". ${ }^{46}$ Here, however, Ibn Khaldun divides the total product - the gains - into used and unused components. He dubbed the part that is used up 'sustenance,' a concept that Karl Marx called 'necessary labour.' For In Ibn Khaldun, the word 'sustenance' is the part of the profit that is utilized. ${ }^{47}$

For modern readers, Ibn Khaldun's usage of the term profit is problematic. However, it should be clear that what Ibn Khaldun calls profit or gain is in fact total

42 Smith, The Wealth of Nations, p. 30.

${ }^{43}$ Ibn Khaldun, op. cit, Vol. II, p. 313.

${ }^{44}$ Ibid., p. 313.

${ }^{45}$ lbid., p. 314.

${ }^{46}$ Ibn Kaldun, op. cit., Vol. II, p. 312.

47 Ibid., p. 314. 
produce. In discussing the constituent parts of the gain, he explains that a man's 'profits will constitute his livelihood, if they correspond to his necessities and needs. They will be capital accumulation, if they are greater than [his needs]'. ${ }^{48}$ Therefore, Ibn Khaldun's division of the total product of labour into 'sustenance' and 'capital accumulation' is similar to the Marxian notion of 'necessary' and 'surplus' labour. In considering labour as a commodity, Ibn Khaldun was a precursor of Karl Marx in another respect. Hel wrote: 'For labour is a commodity, as we shall show later, in as much as incomes and profits represent the value of the labour of their recipients. ${ }^{49}$

Ibn Khaldun's thought on another aspect of value theory is similar to that of David Ricardo's ideas. David Ricardo, in his development of the labour theory of value, was consciously in search of an 'invariable' unit of measurement and arbitrarily selected gold as a commodity which is produced by a method of production that is an average of two extremes: '...the one where little fixed capital is used, the other where little labour is employed, as to form a just mean between them. ${ }^{50}$

Ibn Khaldun also arbitrarily chose gold and silver as 'invariable' measures of value by stating that God created the two precious metal minerals, gold and

48 Ibid., pp. 311-312.

49 Issawi, op. cit. p, 85.

${ }^{50}$ Meek, Studies in Labor Theory of Value. Second Edition. p. 17 
silver, as the "[measure of] value.' ${ }^{\prime 51}$ Moreover, he further imputes that:

[Gold and silver are what] the inhabitants of the world, by preference, consider treasure and property [to consist of]. Even if, under certain circumstances, other things are acquired, it is only for the purpose of ultimately obtaining [gold and silver]. All other things are subject to market fluctuation]. ${ }^{52}$

Adam Smith explains the difference in labour income by comparing between England and Bangladesh, similar to what Ibn Khaldun did four centuries before him, when he compared income in Fez and Tlemcen. It was Ibn Khaldun, not Adam Smith who presented, for the first time, the notion of labour contribution as wealth creation for a nation, by stating that labour increases productivity, and that product exchange in a large market is the prime reason of wealth and prosperity of a nation. In other words, an increase in productivity has a direct propensity to an increase in the wealth and prosperity of a nation or society. On the contrary, the opposite is true: a decrease in productivity may lead to decrease in the economy and income of its society. In addition to the objective theory of value that was discussed above, Ibn Khaldun had touched upon utility as a source of the value and a determinant of the price of a product. His discussion pertaining to utility of a good and its price was nothing new however. Many

${ }^{51}$ Ibn Khaldun, op. cit., Vol. II, p. 313.

52 lbid., p. 314. 
centuries before Ibn Khaldun, Xenophon, as well as Aristotle, had associated the utility of a commodity to its price. Indeed, Ibn Khaldun submits:

For towards the end of a dynasty, and the setting up of a new state, real estate loses its attractiveness, owing to the poor protection afforded by the state and the general conditions of chaos and ruin: its utility is diminished and its price falls, hence it is acquired for a small sum...Now when the new state has firmly established itself and order and prosperity have returned and the country has rejuvenated itself, real estate becomes once more attractive, owing to its great utility, and its price once more rises. ${ }^{53}$

Based on the previous analogy, Ibn Khaldun's selection of precious metals as 'invariable' measures of value was based on in-depth analyses that characterized David Ricardo's selection procedure. This suggests that Ibn Khaldun was consciously in search of an invariable unit of measurement. These comparisons are showing that both men arbitrarily selected precious metals for that purpose. From the foregoing discussion, it is clear that Ibn Khaldun had a rudimentary labour theory of value, a prelude to the consistent, well formulated, and sophisticated versions of the theory by David Ricardo and Karl Marx. ${ }^{54}$

Although Ibn Khaldun has not used the term 'exchange value', it is clear that his intention is the same. Implied

${ }^{53}$ Issawi, op. cit., p. 27

54 Oweiss, op. cit. 
in his statement is the provision of 'use value' as well, since labour was desired because of the value realized from it in the form of output which men wanted and for the supply of which labour was entirely responsible'. ${ }^{55}$ Thus, one can reasonably argue that Ibn Khaldun took the theory of value to the point from where classical economists began their journey. Spengler had best summarized Ibn Khaldun's views on the subject:

Perhaps the most important of the form of cooperation or organization into which men entered was division of labour (by craft or profession rather than by task) which greatly increased output per worker, elevated a community's capacity to produce above that required to supply elemental wants, and gave rise to exchange and commerce in which producers and merchants engaged, with the kind and quantity of what was produced dependent upon the extent of demand and realizable profit. ${ }^{56}$

\section{Conclusion}

Ibn Khaldun's economic theories are unique in that his objective thinking developed not from any theoretical school of thought, but from practical real-life observations and experiences. It can therefore be said that his theories are sound since they were based on an a posteriori or proven inductive empirical bases rather than entirely upon a priori theoretical assumptions, however lofty the ideals of the latter. The widespread rampage of Black

55 Spengler, op. cit.

${ }^{56}$ Spengler, op. cit., p. 46 
Death that brought untold havoc, death and destruction to humans with lasting and devastating consequences for society, and which, on a personal note, deprived him of his close relatives, friends and teachers was perhaps the catalyst which opened his eyes towards embarking on his understanding of the economic system. This human catastrophe helped him to identify a parallel between the rise and fall of civilizations and the rise and the fall of economic surplus, and thus formulated his theory that labour is the true and actual source of value. He thus places labour above natural resources, in that labour per $s e$ is a necessary and sufficient condition for revenue and the generation of wealth and prosperity. It may be presumed that as a $14^{\text {th }}$ century economist, Ibn Khaldun's work may sound rudimentary to the present day analysts. However, his observations and theories were the very foundations for later theories. The idea that the degree of wealth and standard of living of a place has direct relation to the earnings from the actual place where it occurs was taken up later by Adam Smith. Ibn Khaldun's explanations and reasons that influence the difference in labour earnings was later ratified by David Ricardo. Ideas like division of labour and labour value were part of the original contributions of Ibn Khaldun. His labour theory of value is a forerunner to Marxian ideas of surplus value. His choice of gold and silver as 'invariable' measures of value has a later historical parallel in David Ricardo. No doubt, Ibn Khaldu is to be considered the precursor, founder and original contributor of a great number of fundamental economic notions and doctrines, which received official status and recognition centuries after his debut, as they were taken up and further developed by later economists. 


\section{References}

Baeck, Louis. (1994) The Mediterranean Tradition in Economic Thought (London \& New York: Routledge).

Bernardelli, H. (1961) The Origins of Modern Economic Theory. Economic Record, 37: 320-38.

Boccaccio, Giovanni. (1930) The Decameron vol. I (Translated by Richard Aldington illustrated by Jean de Bosschere), Paris.

Boulakia, Jean David C. (1971) Ibn Khaldun: A Fourteenth-Century Economist. Journal of Political Economy, 79: 1105-1118.

Campbell, Bruce M. (1984) In: Richard M. Smith, ed., Land, Kinship and Life-Cycle Cambridge, MA: Publisher pp. 87-134.

Dols, M. W. (May 1979) The Second Epidemic Pandemic and its Recurrences in the Middle East: 1347-1894. Journal of the Economic Social History of the Orient, 22(2): 170-1.

Essid, M. Y. (1987). "Islamic Economic Thought" in Lowry, S. T. (ed.) Pre-Classical Economic Thought. Boston: Kluwer Academic Publishers.

Hamilton, Earl. (1936) Money, Prices, and Wages in Valencia, Aragon, and Navarre, 1351-1500 (Cambridge, MA Harvard University Press)

Herlihy, D. (1997) The Black Death and the Transformation of the West (Cambridge, MA: Harvard University Press), p. 29. 
Herlihy, D. (1997). The Black Death and the Transformation of the West (Cambridge, MA: Harvard University Press), p. 29

Hume, D. (1993) Political Discourses: Bilingual EnglishFrench (1752-1758). (Translated by Fabien Grandjean). (Mauvezin, France: Trans-Europ-Repress), 22 cm, V260 p. Bibliographic notes, index.

Ibn Khaldun (1967) The Muqaddimah: An Introduction to History. Volume I, II, III (Translated by Franz Rosenthal). (London: Routledge \& Kegan Paul).

Ibn Khaldun, (1958) The Muqaddimah: An Introduction to History. (Translated from Arabic by Franz Rosenthal), Vol. 3, Bollingen Series, No. 43. (New York: Pantheon).

Issawi, Charles. (1950) An Arab Philosophy of History (London: John Murray).

Kelly, J. (2005) The Great Mortality, An Intimate History of the Black Death, the Most Devastating Epidemic of All Time (New York, NY: Harper Collins), p. 295.

Koutsoyiannis, A. (1979) Modern Microeconomic (London: Mcmillan).

Kuran, T. (1987). "Continuity and Change in Islamic Economic Thought" in Lowry, S. T. (ed.) Pre-Classical Economic Thought. (Boston: Kluwer Academic Publishers.)

Lewis, Bernard. (1970) In: M. A. Cook, ed. Studies in the Economic History of the Middle East (Oxford: Oxford University Press), pp. 78-92.

Meek, R. L. (1956) Studies in Labor Theory of Value. Second Edition (New York: Monthly Review Press). 
Nashat, M. A. (1945) Ibn Khaldun Pioneer Economist (Le Caire: Imprimerie Nationale Boulac).

Oweiss, Ibrahim. (1988) Ibn Khaldun, Father of Economics, in Arab Civilization, (Joint editorship with George N. Atiyeh). (New York: State University of New York Press), pp. xii, 365.

Postan, Michael M. (1950) Some Economic Evidence of Declining Population in the Later Middle Ages. Economic History Review, $2^{\text {nd }}$ ser. 2, pp.130-67.

Postan, Michael M. (1972) The Medieval Economy and Society: An Economic History of Britain, 1100-1500 (Cambridge, MA: Harvard University Press).

Roll, Eric. (1974) A History of Economic Thought. Homewood (Illinois: Richard D. Irwin Inc.).

Smith, Adam. (1937) The Wealth of Nations (New York: Random House, Inc.).

Schmidt, N. (1967). Ibn Khaldun: Historian, (Sociologist, and Philosopher). New York: AMS

Spengler, Joseph J. (1964) Economic Thought of Islam: Ibn Khaldun. Comparative Studies in Society and History, (The Hague), Vol. VI, pp. 268-306.

Williman, Daniel, ed. (1982) The Black Death: The Impact of the Fourteenth Century Epidemic (New York: Center for Medieval and Early Renaissance Studies). 